Portland State University

PDXScholar

1973

\title{
Chinese Attitudes and Knowledge Concerning Social Services: a Survey of the Portland Chinese Community
}

\author{
Laura Lum Sing \\ Portland State University \\ Wendy Po-Kow Chan \\ Portland State University \\ Peter Tau-Ping Wang \\ Portland State University
}

Follow this and additional works at: https://pdxscholar.library.pdx.edu/open_access_etds

Part of the Chinese Studies Commons, and the Social Work Commons

Let us know how access to this document benefits you.

\section{Recommended Citation}

Sing, Laura Lum; Chan, Wendy Po-Kow; and Wang, Peter Tau-Ping, "Chinese Attitudes and Knowledge Concerning Social Services: a Survey of the Portland Chinese Community" (1973). Dissertations and Theses. Paper 1659.

https://doi.org/10.15760/etd.1658

This Thesis is brought to you for free and open access. It has been accepted for inclusion in Dissertations and Theses by an authorized administrator of PDXScholar. Please contact us if we can make this document more accessible: pdxscholar@pdx.edu. 
LD4349

. A8 4

1973

.$\$ 5$

\author{
CHINESE ATTITUDES AND KNOWLEDGE \\ CONCERNING SOCIAL SERVICES: \\ A SURVEY OF THE \\ PORTLAND CHINESE COMMUNITY
}

by

LAURA LUM SING

WENDY PO-KOW CHAN

PETER TAU-PING WANG

A practicum submitted in partial fulfiliment of the requirements for the degree of

MASTER OF

SOCIAL WORK

Portland State University

1973 


\section{ACKNOWLEDGMENT}

We wish to express our thanks to Dr. Frank F. Miles, Professor, School of Soclal Work, Portland State UnIversity, for his encouragement and advice on our research project.

We also w1sh to acknowledge members of the Chinese Consolidated Benevolent Assoclation Counc1l for the1r cooperation and support.

Special thanks and appreclation are also extended to members of the Portland Chinese community for their response and cooperation. 
TABLE OF CONTENTS

PAGE

ACKNOWLEDGMENT • • • • • • • • • • • • • 11

LIST OF TABLES . . . . . . . . . . . . . . . . v CHAPTER

I. INTRODUCTION . . . . . . . . . . . . . 1

Focus of Research ......... . 3

Chinese in America and Traditional

Cultural Perspectives . . . . . . 6

II. REVIEW OF LITERATURE . . . . . . . . . . 14

III. METHOD OF STUDY . . . . . . . . . . 21

Exploratory Research Design . . . . . 21

Sampling . . . . . . . . . 24

Method of Obtaining Data . . . . . 25

IV. DATA ANALYSIS . . . . . . . . . . 31

General Characteristics of
Respondents .......... 31

Respondent Att1tudes and Knowledge
Concerning Soclal Services..... 34

Comparison of Attitudes and Knowledge

by Select Varlables ........ 38

V. SUMMARY AND RECOMMENDATIONS ...... . 56

Summary and Implications....... . 56

Discussion ............ 58

Recommendations ......... 61

LIST OF REFERENCES . . . . . . . . . . 64 
PAGE

APPENDIX: SUGGESTED USEFUL SOCIAL SERVICES

FOR THE CHINESE COMMUNITY . . • . 67

QUESTIONNAIRE • • . . . . . . . . . . . . 72 


\section{LIST OF TABLES}

TABLE

PAGE

A. Demographic Characteristics of

Respondents . . . . . . . . . 32

B. Overview of Respondent Attitudes and

Knowledge Concerning Soc1al Services ... 35

I. Desire for Information About Local

Social Services, by Place of Blrth . . 39

II. Likelihood of Using Resources, by

Country of B1rth and Type of Problem . . 40

III. Desire for Information About Local

Social Services, by Age . . . . . . 43

IV. Likelihood of Using Resources, by Age

and Type of Problem . . . . . . . . 44

V. Desire for Information about Local

Social Services, by Household Income

Level . . . . . . . . . . . 47

VI. IIkelthood of Using Resources, by

Household Income and Type of Problem . . 48

VII. Likelthood of Using Resources, by

Education and Type of Problem . . . . 51

VIII. Acceptability for a Chinese to go to an

Agency for A1d, by Education . . . . 53 


\section{CHAPTER I}

\section{INTRODUCTION}

The professional social worker needs to understand wide soclal 1ssues, including the culture and cultural background of minority persons and groups in the United States. One minority group with which soclal work has not much contact, and thus has little knowledge about, is the Chinese. Regarding professional soclal work knowledge about minority groups, the Chinese could be considered a "silent minority."

As Rose Hum Lee stated, "Few have undertaken a serious study of the Chinese citizen through the centuries and few have really delved deeply into the life and thought of the Chinese in America."l Further, a review of the soclal work ilterature indicates that little research has been done regarding Chinese att1tudes and knowledge concerning social services. The researchers felt that this type of study should be done in order to contribute to the professional social work body of knowledge concerning Chinese.

The purpose of this research is to examine selected attitudes and knowledge concerning social services, related factors having to do with the use of 
soclal services, and the solving of soclal or personal problems. Another objective of this study is to acquaint professionals with the Chinese cultural and traditional background and thus promote further understanding. In addition, this research is purposed to disseminate information about local social services to the Chinese community.

The research was conducted by three graduate students in the School of Soclal Work, Portland State University, who are all of Chinese herltage and background, two from China, one American-Chinese.

The research began to take shape as certain questions were ralsed by the researchers. For example: Why do social work agencies have few Chinese clients? To what kinds of sources do Chinese turn for aid if they do not turn to social services? How much do Chinese people know about social work agencies?

Answers to questions such as these should be helpful for both the professional body of knowledge as well as Chinese.

Because this is an exploratory study, one major limitation is that the research is of a general nature. Also, this study was limited to the Portland Chinese community, and findings cannot easily be generalized to other Chinese communities in the United States. 
"Portland Chinese community" is used in this research to Include the Chinese living within the Portland city IIm1ts; the term is not used to refer to a particular geographical area within the c1ty.

\section{Focus of Research}

The major alms of this study are placed both on benefiting the professionals in social work, in gaining better understanding of the Chinese, and on helping the Chinese community to become aware of the existence and avallabllity of the soclal services.

The researchers acknowledge, through reviewing I1terature, that the Chinese in America have problems of their own. The fact is true in the past as well as in the present. "The myth that Chinese people have no problems is fallacy."2 As a minority group, it is somewhat more difficult for them to establish their hold in the soclety as compared to the rest of the people in this society. To obtain the help needed, professional services are required. To give the help needed, both professionals and the Chinese must have a more thorough knowledge of one another, both for soctal policy, social action and personal services.

To meet these objectives, three aspects were included in the research design: 
First of all, research questions were employed to find out what information the Chinese had about social services and agencies in the local community, and to what extent they had or would make use of them. Their attitudes about the use of these agencies and services were also examined.

Second, the researchers sought to find the alternative sources of assistance the Chinese ut111ze, if they did not turn to social work agencies services. Third, one intent of this study was to assess whether certain personal, socioeconom1c, and cultural factors were significantly related to understanding and use of the social services. Knowledge of different nurtural environments, different family backgrounds, different social values and norms, enable one to distinguish individuals from the community. Such understanding will be useful in helping the professional employ different approaches to deal with the Chinese clients as persons.

A small section of this study is also designated to laying a framework for reference use of the professlonal, through reviewing the common and traditional background. Since truths of Chinese in America are so clouded by stereotyped images that the general public as well as the professional in social work have, some 
distortions and misunderstandings toward the Chinese exist. Countless Americans st1ll 1dentify the Chinese as an industrious, hard working, self-rellant "coolie." Abstract and generalized 1mages are reinforced by mass media, and perhaps the Chinese themselves employ favorable stereotypes as defense mechanisms to protect themselves from making their problems known to the public. Therefore, another objective of the study became to clarify some of the misconceptions and to present a clearer plcture of the Chinese in America to the professional as well as to the general public.

Because of inherited tradition and nature, the Chinese in America are often 1gnorant of the existence of the social agencies and avold seeking assistance from them. A vlew taken by an American-Chinese banker in New York is typical: "We belleve welfare should be used only as a last resort." 3 To help to change this situation, the research itself serves as a tool for provoking the awareness of Chinese about soclal services. A pamphlet from the Tri-County Counc1l which lists the major local soclal services and agencles has been sent out by the researchers to respondents in the study who expressed an interest in or need for knowing these agencies and services. 
Chinese in America and Traditional

Cultural Perspectives

To ald the soclal worker in dealing with the Chinese client, it may be helpful to examine the historlcal background of Chinese in America and some traditional cultural perspectives.

Demographic Characteristics and Overview

The population of the Chinese in America has increased dramatically in this century. It has nearly tripled in size in the years 1950 and 1970, from 117,629 to $435,062.4$ The increase of population within the group is significant; although when compared to the total population in the United States, the total remains small.

From the very beginning of the urban trend, the Chinese have shown a tendency to settle in metropolitan areas of c1ties over 100,000 population. 5 In the early days of dispersion the Chinese tended to locate only in a small clty or a rallroad junction. But following the diminution of persecution and better opportunity for education, the Chinese in America had a better chance to move into the metropolitan areas, and then to compete with other Americans. Opening restaurants was often typical. 
From humble beginnings, the Chinese have gradually elevated themselves within the larger soclety. These transformations have direct or indirect Impact on the decline of "Chinatowns". In Amerlca, which had resulted from the migration and settlement of persons with a culture, religion, language, 1deology, or race which differed from those of the larger society. More persons representing the original immigrants now live outside ghetto areas. This movement contributed to the fact that "the Chinese had adopted more behavior patterns of the larger soclety and supported new norms and $f$. values." 6

Support of the new norms and values, however, does not imply that the course of the acculturation, integration, and even the adjustment of the subgroup in the larger soclety is without problems. Many problems do, In fact, exist. For instance, the generation gap between youngsters and elders 1s present. Because of the different lengths of settlement, the bearers of culture are different. To the native born Chinese, the Chinese not born in America are as forelgn as they are to other Americans. They are so different in ancestry, In the patterns of behavior, the norms, and values, that a problem of adjustment is created in getting along with their own people, as with other Amerlicans. 
The American-born Chinese seeks Identification and status with other American-born persons in an effort to become more fully particlpating members of the larger soclety. However, first generation Chinese parents desire traditional ways, thus tension is initlated between the two generations. Then cultureconflicts between parent-child become imminent. A scholar predicted that,

unless the social agencles of the large soclety step in to provide corrective and preventive services, juvenile delinquency may increase, as a part of the whole process of assimilation and integration into the American social milleu.7

Th1s problem is only one of the samples of various problems existing in the Chinese community. How to solve and to help the Chinese cope with these problems is partly the responsibility of the professionals.

Proflle of the Ghinese in Fortland

The Chinese community in Portland emerged around $v$ the $1870^{\prime} \mathrm{s}$, when the transcontinental rallroad was extended to the far West. The population of Chinese in Portland reached its peak of about 10,000 around the and it ras the larged ehine rtown during that Resiod year 1900\% The size of the Chinese community dropped to about 3,000 when the rallroad was completed around 1920. In 1970, 3,095 Chinese lived in the Portland metropolitan area including Washington, Clackamas, and 
Multnomah counties. $\not$ The Chinese reside in all parts of Portland now, instead of concentrating in Chinatown. At one time Portland did have a flourishing Chinatown, which was established in the 1890's. At that time, it was located in the west side of Portland near the Willamette River, around Second and Hardwood Avenue (now known as oak street) $\rho$

Many former ChInese laborers of Portland opened business operations in this area. When Communists took over malnland China, the UnIted States halted Importation from Red China, and Chinatown started to decline as a result of the loss in business. Some remnants of this era still exist in the old Chinatown area today.

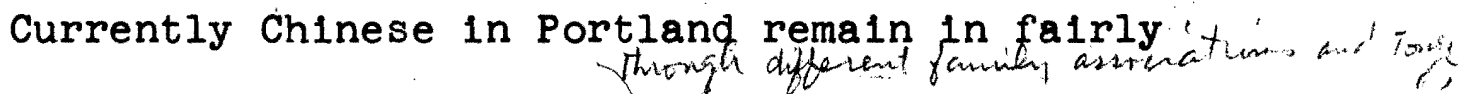
close contact with one another although they reside in various parts of the area. As in other chinese communities in Amertca, the Chinese have their own organization in Portland. For he C.C.B.A., Chinese Consolidated Benevolent Association, was formed for the welfare of the whole Chinese community, especlally the people who were unable to support themselves. (In the (past the Chinese have seldom turned to public help, ) which often "was promptly denied to them on the basis) that they were not United States citizens."10 
Generally speaking, most of the Chinese now in Portland are showing new faces to the dominant soclety. They own various businesses; restaurants and grocery stores are typical. There are many well-educated Chinese who have entered various professions and services. This is evidence that the Chinese in Portland have progressed a long way in their degree of assimilation into the larger community. However, it is not surprising that they remain as a subculture within the larger Portland community and st11l thave not been completely accepted by the larger community ${ }^{1 / 1}$ one wim the the

Traditional Background and Ph1losophical Perspect1ve

The Chinese who dwell elther in "Chinatown" or in neighborhoods with other Amerlcans, more or less retain some of their traditional background and heritage and thus it is helpful to consider traditional and cultural background to ald in understanding this minor1ty group.

The Chinese have long been attached to the fam1ly system, which was highly respected as a virtue in traditional society. Individuals in the family had to adhere to the securlty of their primary kinship organization. The strong attachment to the primary group makes the Chinese people feel secure only in their 
primary human relationships. The primary kinship relationship thereby nurtured the 1dea of complete selfrellance and self-sufficlency of the extended family. When the individual was very young, he was taught that his security lay within the family (mutual ald system) and not in outside assistance. The fact that the Chinese in America hesitate to seek help from "out- $\Varangle$ Xsiders" of the larger community can be interpreted to be a remnant of this tradition.

Another traditional characteristic in the Chinese culture is to give respect and obedience to elders and authority figures. Individuals are taught to keep to their assigned status and rank within their families. They also are taught to repress their own desires, to inhibit aggressions. "Face-saving" was used as a vital tool of social control; individuals were instructed from the1r youth not to embarrass others and not to be caught in embarrassing situations. In a larger family many interests must be reconclied, and offenders are Judged by many elders and peers, not only by their parents (and siblings) Organizations formed for reconcliling (the brawls and) disputes were common in every Chinese community in the past. The so-called "Bow Leong Bing Kong Soclety" in the Portland Chinese community is one such organization. Besides keeping 
Justice in the Chinese community, this soclety served as the basis of protecting Chinese who had no family ties or relatives in the country.

The above information describes the general situation of Chinese in America, and in Portland, as well as buegrounds traditional cultural (perspectives) and serves to place In perspective the research objectives. 
CHAPTER NOTES

$1_{\text {Rose Hum Lee, The Chinese in the United States of }}$ Amerlca, Hong Kong University Press, 1960, p. 4.

${ }^{2} \mathrm{Pe} 1-\mathrm{Ng}$ or Chen, "The Chinese Community in Los Angeles," Soc1al Casework, December 1970, Vol. 51, No. 10, p. 591 .

3"Success Story of One Minority Group in U.S.," U.S. News \& World Report, December. 26, 1966, p. 73.

${ }^{4}$ Betty Lee Sung, Mountain of Gold, The MacMillan Company, New York, N.Y., 1967, p. 111; General Population Characteristics, Bureau of Census, U.S. Department of Commerce, 1970, United States Summary, p. 2-263.

${ }^{5}$ Rose Hum Lee, op. c1t., p. 53.

I Ib1d., p. 262.

7 Ib1d., p. 351 .

8 General Population Characteristics, op. cit., pp. 39-59.

9 Pauline Gaskill, "Ecology of Portland Chinese," unpublished paper for Social Ecology 426, Portland State University, 1968, p. 4.

${ }^{10}$ Ib1d., p. 12.

${ }^{11}$ Ibid., p. 13. 
CHAPTER II

\section{REVIEW OF LITERATURE}

Little pertinent information has been published with regard to our research subject. The researchers made a thorough I1brary research of the I1terature and found only scattered relevant material.

Inquiries to The University of Cal1fornia, Berkeley, The Columbla University, and The University of Ch1cago librarles were all unproductive.

To shed some light on how Chinese in America deal with their problems, their feelings about the adequacy of the social services existing in the community, and in what situations they would make use of the soclal service's, the present paper is an initial attempt at an analysis of Portland's Chinese community within the Iimitation of the research sample.

The researchers feel that the probable magnitude of the problems of the Chinese, who I1ve in America, seems to justify more attention than has been given to them. We feel that the following two contrasting statements, which appeared in the same perlodical article, reflect the true condition of the Chinese in America as the researchers are famlliar with them: 
One such minority, the nation's 300,000 Chinese Americans, is winning wealth and respect by dint of 1ts own hard work.1

Not all Ch1nese Amerlcans are rich. Many, especlally recent arrivals from Hong Kong, are poor and cannot speak English. But the large majority are moving ahead by applying the trad1t1onal virtues of hard work, thrift and moral1 ty.2

Traditionally, the clan assoclations existing in different big c1ties in the United States were, and st11l are to a great extent, respons1ble for the welfare of the Chinese Amerlcans. Their maln purpose is to help Chinese people who belleve that Public Welfare should be used only as a last resort. The clan assoclations were established around 1900. All the familles with the same surname belong to a clan assoclation bearing that name. These clan assoclations perform many useful functions. They used to settle disputes among members and between assoclations. The clan assoclations are concerned with the welfare of clan members and newly arrived families.

These clan assoclations usually act in the capacity of insurance or mutual benefit associations, and assume responsibllity for the welfare of all its members. It is expected that a member would appeal to his own clan assoclation for help before asking those outside his family group. 3 
The clan association seems to be the nearest thing to a welfare agency that the Chinese have experienced. 4

Above all these associations is the Chinese Consolidated Benevolent Association, which operates at the highest level.

During the depression of the $1930^{\prime} \mathrm{s}$, the Chinese people banded together under the direction of the C.C.B.A. and formed their own welfare system to take care of the Chinese who were unable to support themselves. They rationed food and clothing to these people until there were no more funds. 5

In the early $1900^{\prime} \mathrm{s}$, there was little chance for the Chinese to I1ve outside of Chinatown because of language difficulties, prefudice, and lack of business opportunities else-

Since the end of World War II, Chinese have been accepted gradually by the majority group; they are no longer confined to Chinatown.7

The Chinese people's problems become more known to other people once the Chinese have come into contact with the outside world.

It is obvious to all of us that Chinese people would have personal and fam1ly problems which grow out of the process of acculturation. In the old Chinese traditional society in China, there were strong social and kinship ties. Personal and family problems were 
usually solved with the help of relatives and friends. In this country, the traditional, social and kinship tles have been broken down because the great physical distances exist among the Chinese people. There is a high 1111 teracy rate in English among the old 1mm1grants. Some of the old male immigrants have lost their wives and have gone through some hardships assoclated with prolonged "bachelor" 11fe. They become alcohollc or mentally 111 to a certain extent due to Ioneliness and depression. On top of these there may be language problems; it is especially true of newly arrived Immigrants. They do not know where to find a job. They are caught in between two cultures. The cultural adjustment process is a long and difficult one.

In Pe1-Ngor Chen's article, "The Chinese Community in Los Angeles," he mentioned that
A small percentage of the total Chinese population is in dire need of help. Considering the point of view of the intensity of their problems, the group most in need of help is the elderly. This group is followed by the recent immigrants from Hong Kong and Talwan and the Youth. A large number of the elderly Chinese live in poverty and fall to request financial assistance from the soclal agencies because of their language barrier and 
also because of their sense of shame. In Chinatown, truancy, the use of drugs and narcotics, and petty thefts have been growing problems.

Chinese people are still being taught in their familles about the old Idea that people should depend on their own efforts--not a welfare check--in order to reach Amerlca's promlsed land. Again the concept of self-reliance comes in. In New York C1ty, the head of the Chlnatown Planning Counc1l recently sald that

$$
\begin{aligned}
& \text { while most Chinese are st11l } \\
& \text { reiuctant to accept public welfare, } \\
& \text { somewhat more are applying for } 1 t \\
& \text { than in the past. We are try } 1 \text { g to } \\
& \text { let Chinese know that accepting pub- } \\
& \text { lic welfare is not necessarily the } \\
& \text { worst thing in the world. }
\end{aligned}
$$

In a thes1s written by Charlotte o1 Quon Wong,

she sald that

$$
\begin{aligned}
& \text { the agency, Chinese cases were few . - . } \\
& \text { The Chinese cases showed that requests } \\
& \text { were for a speciflc kind of help, e.g., } \\
& \text { flnanclal assistance, child placement, } \\
& \text { employment, etc., and that none came } \\
& \text { for help with marital or parent-child } \\
& \text { relationship problems.10 }
\end{aligned}
$$

The fact is that "In general, marital problems between a couple in a Chinese family are seldom known to outsiders."1l "Chinese women have so much pride that they seldom tell anyone thelr marltal problems."12 In Wong's study, actual divorces were scarcely known among 
first generation Chinese Americans. In the second generation divorces were still rather rare. There was great reserve in most Chinese as far as discussing personal problems was concerned. Often the gradual assimilation of the second generation American Chinese was a great step forward as compared to the first generation in speaking about one's own personal problems. In summary, of the professional 11terature reviewed, it seems that any difficulty or friction in a Chinese family is usually settled within the immediate family group due to the strong family ties. The clan associations and the Chinese Consolidated Benevolent Assoclation seem to be the nearest thing to a welfare agency from which Chinese do get help. In general, Chinese have little knowledge and awareness of what social work involves. All this does not prove that the Chinese in America have no personal or family problems. 
CHAPTER NOTES

1 "Success Story of One Minority Group in U.S.," U.S. News \& World Report, December 26, 1966, p. 73. ${ }^{2}$ Ib1d., p. 74 .

${ }^{3}$ Charlotte 01 Quon Wong, "Personal Problems as Defined in Chinatown," unpubilshed Master's thes1s, New York School of Soclal Work, Columbia UnIvers1ty, December 1948 , p. 16.

${ }^{4}$ Ibid.

5 Pauline Gask111, "Ecology of the Portland Chinese," unpublished term paper for Soclal Ecology Class 426, Portland State University, 1968, p. 12.

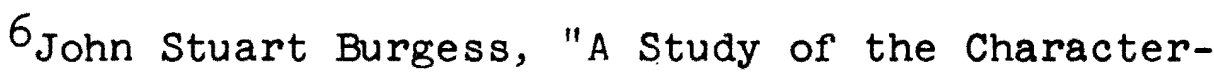
istics of the Cantonese Merchants in Chinatown, New York, as shown by Their Use of Leisure Time," unpubIished Master's thesis, Columbia University, 1909, pp. 25-26.

7D. Y. Yuan, "Chinatown and Beyond: The Ch1nese Population in Metropolitan New York," Phylon, 27: 321-332, Winter, 1966, p. 331.

${ }^{8}$ Pe1-Ngor Chen, "The Chinese Commun1ty in Los Angeles," Soclal Casework, Volume 51, Number 10, December 1970, p. 592 .

9 "success Story of One Minority Group in U.S., op. c1t., p. 76 .

${ }^{10}$ Wong, op. cit., p. 1 .

11

Ibid., p. 34 .

${ }^{12}$ Ib1d., p. 35. 
Exploratory Research Design

In the research design we sought to obtain knowledge about what the Chinese people think about the social agencies and services, how familiar they are w1th the different kinds of soclal services existing in the community, and what kinds of attitudes they hold concerning social services. Our study was primarily an exploratory one in nature. It had the purpose of formulating a research problem and then other researchers could make use of our findings to develop further studies.

An exploratory study may, however, have other functions: increasing the investigator's familiarity with the phenomenon he wishes to investigate in a subsequent, more highly structured study, or with the setting in which he plans to carry out such a study; clarifying concepts; establishing priorities for further research; gathering information about practical possibilities for carrying out research in real-11fe settings; providing a census of problems regarded as urgent by people working in a given fleld of soclal relations. I

To formulate our research top1c, we engaged ourselves in reading materials such as books, Journals, 
perlodicals and other publications relevant to our research study. We read materlals about Chinese people, culture, philosophy and history. This continued all through our research process. Group discussions took place from time to time to bring in new 1 deas and problems. Questions ralsed were the following:

A. To what alternative sources of ald do the Chinese in Portland turn if they do not turn to soclal work agencies and/or services?

B. What are some of the att1tudes of the Chinese in Portland concerning soclal work agencles and/or services?

c. What kind of soclal work information resources are most helpful and desirable to the Chinese in Portland?

D. In what kind of situations do the Chinese in Portland actually use soclal work agencles and/or services?

E. Do the younger Chinese people or does the younger generation know more about soclal work agencles and services and are they more apt to use them?

These questions gave us a theme as to what kind of research problem we should formulate and some of the procedures to be followed. 
From the researchers' background and contact with Chinese people, some initlal Impressions had come to our minds:

A. Chinese people do not know much about local soclal work agencles and services.

B. The traditional 1dea that seeking help outside the famliy is not acceptable is still held by members of the Chinese community .

C. Acculturation would have changed some of the Chinese people's thought that seeking help outside the family is unacceptable.

The Impressions arose from our knowledge of the Chinese and their culture. These underlying impresslons might not hold true in different Chinese communities, but they might raise interesting questions and stimulate further research. This exploratory study was not directed toward absolute answers to our questions, but 1ts findings and conclusions may help other professional soclal workers and sclentists to create a more meaningful soclal study and diagnosis and valuable recommendations. These may, in turn, result in more knowledgeable and Improved soclal services for Chinese people in this country. Hopefully, this study may add to the professional soclal workers' and other people's knowledge of the Chinese. 
Before the study was carried out, the researchers realized that in Chinese tradition, it was customary to go to leaders in the Chinese community for "cooperation and blessing." We wanted to make our study known to as many Chinese as possible in Portland. One of the researchers went to a meeting of the Counc1l of the Chinese Consolidated Benevolent Association. The C.C.B.A. is the organization which represents the Chinese community and attempts to maintain Chinese culture in this country. The Council is made up of elected leaders of the Chinese community. In that meeting, the researcher told the Council members of the C.C.B.A. about our research project and familiarized them with our plan. The C.C.B.A. publishes the oregon Chinese News, which is the only local Chinese newspaper; the Counc1l members agreed that we should pubI1sh articles concerning our study in the Chinese newspaper.

\section{Sampling}

Our sample was 355, from names on the oregon Chinese News malling list; most were names of individuals who were heads of familles. All the addresses, which we had gotten, were within the Portland city limits. The sample size of 355 seemed to be a number 
which we would be able to manage, therefore we used all the names on the newspaper malling list.

We belleve the Oregon Chinese News malling list contains the most complete list of Chinese families residing in the clty of Portland. It was complled after a fairly thorough search of the Portland Chinese population by Chinese community leaders and is kept current by members of the Chinese Consolidated Benevolent Association.

Method of Obtaining Data

We had only three academic terms to finish our study; therefore we chose the method of malling questionnaires to the respondents.

We realized that the return rate would be low from our understanding of Chinese and our own background. We knew that Chinese people are not famlliar w1th answering research questionnaires. Not much social research or many public opinion polls have been conducted in China. The Chinese do not like the idea of having other people know about their feelings or about information concerning them and their families. The reason may be due to a cultural tendency toward reservation. The researchers still embraced the hope that enough responses would come back so that our data would be of significance. 
From the researchers' point of view, the information obtained from the return responses of the questionnaires was the subjective feeling and attitude of respondents. There was no way to find out whether the respondents had misunderstood some of the questions. Unconscious blas, vagueness of the question, emotional condition at the time of responding and lack of information were the undetectable factors which might have influenced the outcome of the study. The findings obtained could not be equated with findings that might result from interviews. If the method of interviewing was used, unclear questions or doubts could be polnted out by the respondents and immediate correction could have been made. But this method would have been too time consuming.

The completed questionnaire contained two pages and was written in two versions: Chinese and English. A head letter was attached to each questionnaire; the head letter was also written once in English and once in Chinese. The respondents could then respond to the language they knew best.

The head letter introduced the researchers to the respondents, giving some background information about the researchers and the research project. We also told the respondents we had gotten their names from the 
Oregon Chinese News malling 11st. The researchers stressed the confldentiality of the responses. We told them that the major findings of the study would be published in the Oregon Chinese News after the data had been analyzed and complled.

The questionnalre as finally completed covered six major categories. The flrst one contained the base information about the respondent and some information such as relationship to the head of the household, educational level and the total income for household for the previous year (1971). The second major category included culture related background information such as the language spoken in the household, the country of b1rth, the length of time lived in the United States, and which generation Chinese in America. The third category asked questions concerning understanding of soclal work services and the concept of social work. The researchers asked the respondent questions such as whether he had ever used the services of a social work agency; how familiar he was with the kinds of services offered by soclal service agencles, etc. The fourth category contained four situational questions which were also called hypothetical questions because the respondents were asked where they would first go for aid in a certain hypothetical situation (1.e., financial emer- 
gency, marital problems, child disclpline problems, and unemployment). The fifth category included four questions geared toward measuring attitudes concerning social service agencles. The researchers asked the respondent about the usefulness, adequacy and acceptablilty of going to the soclal work agencles. We also asked the respondent if he thought there would be a language barrier if he went to an agency to obtain some type of a1d. The last category included two questions. One asked the respondent if he would like to know the names and the services of the public and private soclal service agencles in the Portland metropolitan area. The other one was an open-ended question asking the respondent to state the most useful kind of service that a social work agency could offer to the Chinese community in Portland. At the end of the questionnalre, we stated that additional comments were welcome.

Before the questionnalres were sent out, we put an article in the Oregon Chinese News in the June, 1972 1ssue. We mentioned that the questionnaires would be sent out during the middle of August, 1972. We stated the purpose of our study and stressed the confidentiality of the responses. A second article was put in the August, 1972 Oregon Chinese News to remind the Chinese community of the forthcoming survey. We 
started malling out the questionnalres the middle of August. The majority of the responses came back within about a one-month period.

Twenty-two questionnalres were returned by the Post office or by other sources who indicated that these twenty-two addresses and/or places of resldence were no longer current. Seventy-f1ve persons responded and returned the questionnaires. Of the seventy-five respondents, two stated that they were Caucasian; their responses were not tabulated in the data analysis.

As will be seen in the next chapter, the sample is probably blased in the direction of higher education and income. Projections to the general Chinese community must be carefully made.

As the respondents returned the questionnaires, the responses were recorded; after all responses had been recelved they were tabulated and then crosstabulated according to four select variables--country of birth, age, household income and education. Tests of signiflcance were not run because they were not found to be appropriate. 
CHAPTER NOTE

\author{
${ }^{1}$ Claire Sellt1z, Marle Jahoda, Morton Deutsch, and \\ Stuart W. Cook, Research Methods in Soclal Relations, \\ Henry Holt and co., New York, 1959, p. 51.
}


CHAPTER IV

\section{DATA ANALYSIS}

Description and analysis of responses for the study are presented in three parts: the first part describes some general characteristics of the respondents, the second part concentrates on description of respondent attitudes and knowledge concerning soclal services, and the third part contains a comparison of attitudes and knowledge concerning soclal services by select variables.

General Characteristics of Respondents

Demographic characteristics of the respondents are described in Table A.

The seventy-three respondents described here are all of Chinese herltage; they range in age from twentyone to seventy-seven years, with a mean age of 45.7 . Age was reported for sixty-four of the respondents. The respondents hold a varlety of occupations and represent households which vary in size from a one person household to a nine person family. 
TABLE A

DEMOGRAPHIC CHARACTERISTICS

OF RESPONDENTS

\section{COUNTRY OF BIRTH}

\begin{tabular}{|c|c|}
\hline $\begin{array}{l}\frac{\text { China }}{\text { (Including mainland China, }} \\
\text { Talwan, and Hong Kong) }\end{array}$ & $43 \% *$ \\
\hline U.S.A. & $55 \%$ \\
\hline Other & 2 persons \\
\hline GENERATION CHINESE IN & AMERICA \\
\hline F1rst Generat1on & $42 \%$ \\
\hline Second Generation & $44 \%$ \\
\hline More Than Third Generation & $11 \%$ \\
\hline Unsure & 2 persons \\
\hline$\frac{\text { LENGTH OF RESIDENCE }}{\text { UNITED STATES }}$ & IN THE \\
\hline Under 5 Years & 2 persons \\
\hline Between 5 and 10 Years & $11 \%$ \\
\hline Between 10 and 15 Years & $6 \%$ \\
\hline Over 15 Years & $81 \%$ \\
\hline
\end{tabular}

SEX

Male

$61 \%$

Female

$39 \%$

* Percentages are rounded to the nearest whole number. 
TABLE A--Continued

MARITAL STATUS

Married

$78 \%$

Widowed 9\%

Single

$12 \%$

Divorced 1 person

EDUCATION

Some Grade School

$8 \%$

Grade School

2 persons

High School

$25 \%$

Some College

College Graduation

$17 \%$

Technical/Vocational Training

$47 \%$

8 persons*

HOUSEHOLD INCOME (1971)

$\$ \quad 0--\$ 3,999 \quad 5$ persons $\$ 12,000--\$ 15,99921 \%$

$\$ 4,000--\$ 7,999 \quad 11 \%$

$\$ 16,000$ and up

$31 \%$

$\$ 8,000--\$ 11,000 \quad 29 \%$

LANGUAGE SPOKEN IN HOUSEHOLD

Chinese

3 persons

Both

$79 \%$

Engl1sh 26\%

Other

$0 \%$

\section{RACE OF MAJORITY OF FRIENDS}

Chinese 56\% Non-Chinese 31\% Both 13\%

*The elght persons who had technical/vocational training stated that they had this training in addition to their other education. 
Summing up the majority* responses regarding general characteristics of the respondents, most of respondents in this exploratory study have lived in the United States for more than fifteen years and are elther f1rst or second generation Chinese in America; slightly more than half are American born. There are more male than female respondents, and more married than unmarried ones. The mean age of the respondents 1s 45.7 . Most of the respondents speak both the English and Chinese languages in their households; and more than half of the respondents have mostly Chinese frlends, rather than non-Chinese friends.

Respondent Att1tudes and Knowledge Concerning Soc1al Services

An overview of respondent attitudes and knowledge concerning soclal services is given in Table B. Discussion of respondent knowledge concerning soclal services is presented first in this section. Of the respondents, only flve persons had ever used the services of an agency, leaving ninety-three per cent who had not.

\footnotetext{
*The term "majority" is used to mean fifty per cent or more.
} 
TABLE B

OVERVIEW OF RESPONDENT ATTITUDES AND KNOWLEDGE CONCERNING SOCIAI SERVICES

\section{REPORTED FAMILIARITY WITH KINDS \\ OF SERVICES OFFERED}

Very Familiar

6 persons

Unfamiliar $\quad 58 \%$

Somewhat Familiar $33 \%$

NEEDED SERVICES AND NOT KNOWN

APPROPRIATE AGENCY

$\underline{\text { Yes }}$

4 persons

No

$93 \%$

FIRST SOURCE OF AID IN A FINANCIAL EMERGENCY

Commercial Agency

$31 \%$

Friend

2 persons

Relat1ve

$40 \%$

Social Service Agency

5 persons

Other

4 persons

Would Not Seek Help

$13 \%$

FIRST SOURCE OF AID WITH

MARITAL PROBLEMS

Friend $20 \%$ Social Service Agency $11 \%$

Minister 14\% Other 5 persons

Relative 11\% Would Not Seek Help 38\% 
TABLE B--Continued

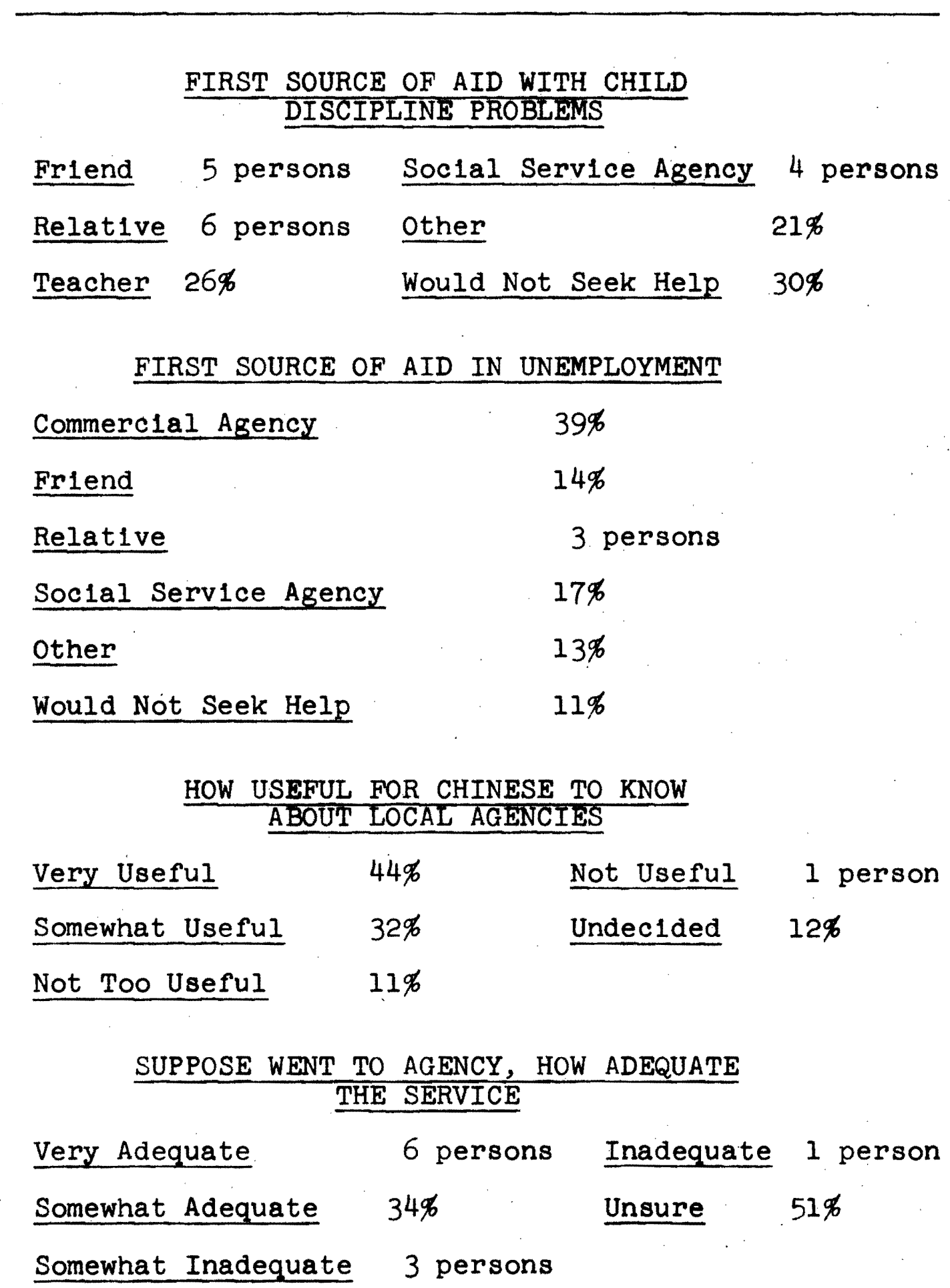


TABLE B--Continued

HOW ACCEPTABLE FOR CHINESE

TO GO TO AGENCIES

Very Acceptable

$34 \%$

Somewhat Acceptable

$34 \%$

Somewhat Unacceptable

2 persons

Unacceptable

1 person

Unsure

$27 \%$

\section{EXISTENCE OF LANGUAGE BARRIER} IF ONE WENT TO AGENCY

Yes $18 \% \quad$ No $82 \%$

DESIRE NAMES AND SERVICES

OF LOCAL AGENCIES

Yes $68 \%$ No $32 \%$

MOST USEFUL SERVICES FOR CHINESE COMMUNITY

(Open-Ended Question)

1. Care of and assistance to the aged

2. Language education for non-English speaking Chinese

3. Vocational help

4. Health and medical care

A more complete list of suggested services is included in the Appendix. 
Responses with respect to attitudes were more varled than those regarding knowledge about social services. A large majority of the respondents reported having little knowledge of services; however, pertaining to att1tudes, a majority of the respondents reported only that a language barrier would not exist if they went to an agency and that they would like to know the names and services of the public and private social service agencies in the Portland metropolitan area.

\section{Comparison of Att1tudes and Knowledge}

\section{by Select Variables}

This section compares respondent att1tudes and knowledge concerning soclal services according to four independent variables: country of b1rth, age, household income, and education. These four variables were found to be the most discriminating ones.

Country of Birth

Table I shows respondent desire for the names and services of the public and private social service agencles in the Portland metropolitan area. 
TABLE I

DESIRE FOR INFORMATION ABOUT LOCAL SOCIAL SERVICES BY PLACE OF BIRTH

Desire Information

Yes No

China Born

22

U.S. Born

25

15

Concerning knowledge about social services, there was little difference between respondents born in China and those born in the United States. The majority of both groups had never used the services of an agency and were unfamiliar with the kinds of services offered. As Table I shows, the majority of both groups wanted to know about local social services, but a proportionately larger number of those born in China wanted this information.

Table II shows responses to whether social service agencies would be sought as a first source of aid in four problem situations. 
TABLE II

LIKELIHOOD OF USING RESOURCES, BY COUNTRY OF BIRTH AND

TYPE OF PROBLEM

\begin{tabular}{|c|c|c|c|c|}
\hline \multicolumn{5}{|c|}{ FINANCIAL EMERGENCY } \\
\hline & Agency & Other* & Seek & No Help \\
\hline China Born & 2 & 22 & & 4 \\
\hline U.S. Born & 3 & 32 & & 5 \\
\hline
\end{tabular}

MARITAL PROBLEMS

$\begin{array}{lccc} & \text { Agency } & \text { Other } & \text { Seek No Help } \\ \text { China Born } & 2 & 11 & 12 \\ \text { U.S. Born } & 5 & 20 & 11\end{array}$

CHILD DISCIPLINE PROBLEMS

$\begin{array}{lccc} & \text { Agency } & \text { Other } & \text { Seek No Help } \\ \text { China Born } & 2 & 16 & 9 \\ \text { U.S. Born } & 2 & 22 & 10\end{array}$

UNEMPLOYMENT

Agency Other Seek No Help

China Born

5

17

5

U.S. Born

6

28

3

* "Other" includes primarily relative and friend, but, where appropriate, includes commercial agency, teacher, minister. 
Regarding respondent attitudes about social services, in both groups of respondents only a few persons stated that they would first go to a soclal service agency in a financial emergency, with marital or child discipline problems, or in unemployment. The largest proportion of the minority who would first go to an agency would do so in the event of unemployment.

With regard to the financlal emergency situation, there existed a difference in modal responses between the two groups. American born respondents would first go to a "relative" (seventeen responses, $n=39$ ), while "commercial agency" and "relative" (ten responses each, $\mathrm{n}=28$ ) were both c1ted by those born in China. There was little difference between groups in marital and child discipline problem situations. "I would not seek any help" was the modal response in both cases; however, pertaining to child discipline problems, American born persons also listed "teacher" (nine responses, $\mathrm{n}=34$ ), and "other" (elght responses, $\mathrm{n}=34$ ) close behind the modal response (ten responses). In the event of unemployment, the majority of American born respondents would go to a commerclal agency, while the responses of China born persons were more varled: "commercial agency" (six), "friend" ( $1 \mathrm{x}$ ), and "social service agency" (flve), $n=27$. 
There was little difference between groups with regard to the usefulness for Chinese community members to know about local soclal services; the majorlty of both groups felt such information to be "very useful" (modal response) or "somewhat useful." "Unsure" was the modal response given by both groups regarding supposed adequacy of services. The majority of both groups also agreed that it is "very acceptable" or "somewhat acceptable" for a Chinese person to go to an agency to obtain some type of ald. The majority of both China and American born respondents also felt that a language barrier would not exist if they were to go to an agency. Of the minority who felt such a barrier would exist, the larger proportion was born in China (elght responses, $\mathrm{n}=30$ versus four responses, $\mathrm{n}=40)$.

Age

The mean age of the respondents was 45.7; for purposes of comparison and analysis, the respondents have been divided into two groups: those over age fortyfive and those age forty-five and younger.

Table III shows respondent desire for the names and services of the public and private social service agencles in the Portland metropolitan area. 
TABLE III

DESIRE FOR INFORMATION ABOUT LOCAL

SOCIAL SERVICES, BY AGE

\begin{tabular}{|c|c|c|}
\hline & \multicolumn{2}{|c|}{$\begin{array}{l}\text { Desire Information } \\
\text { Yes }\end{array}$} \\
\hline & & \\
\hline Over Age 45 & 26 & 7 \\
\hline 45 and Younger & 18 & 12 \\
\hline
\end{tabular}

With respect to knowledge about soclal services, there existed little difference between the two groups. The majority of both those over age forty-five and those age forty-f1ve and younger had never used the services of an agency and felt unfamillar with the kinds of services of fered. Also, regarding the desire to know about local soclal services, as shown in Table III, there was little difference between groups, with the majority of both wanting this information. However, a proportionately larger number of those who sald they wanted the information were over forty-five. Table IV shows respondents' estimation of whether they would seek social service as a first source of ald in four problem situations. 
TABLE IV

LIKELIHOOD OF USING RESOURCES, BY AGE AND TYPE OF PROBLEM

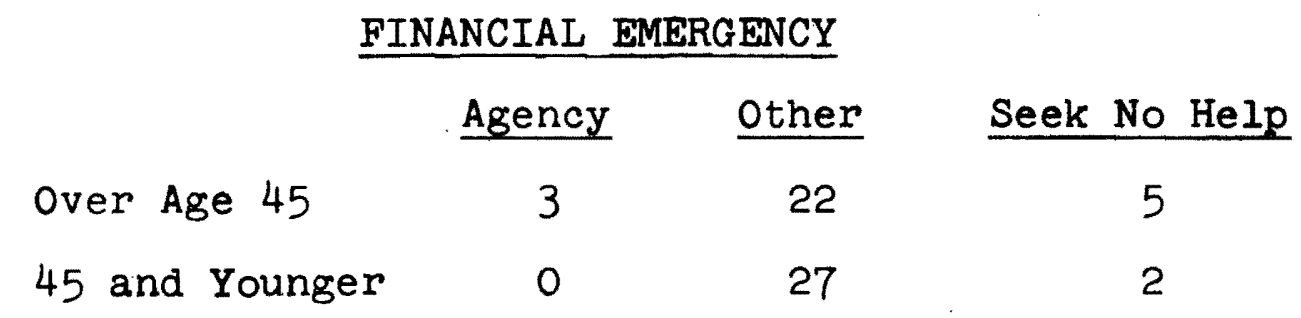

MARITAL PROBLEMS

$\begin{array}{lcccc} & \text { Agency } & \text { Other } & & \text { Seek No Help } \\ \text { Over Age } 45 & 4 & 11 & 13 \\ 45 \text { and Younger } & 2 & 24 & 4\end{array}$

CHIID DISCIPLINE PROBLEMS

\begin{tabular}{|c|c|c|c|}
\hline & Agency & Other & Seek No $\mathrm{Help}$ \\
\hline Over Age 45 & 2 & 17 & 10 \\
\hline 45 and Younger & 2 & 21 & 6 \\
\hline
\end{tabular}

UNEMPLOYMENT

$\begin{array}{lccc} & \text { Agency } & \text { Other } & \text { Seek No Help } \\ \text { Over Age } 45 & 6 & 16 & 5 \\ 45 \text { and Younger } & 5 & 25 & 1\end{array}$


Regarding respondent attitudes concerning soclal services, there was little difference between groups as far as first going to an agency in the listed problem situations; only a small number of persons in each group would flrst turn to an agency for help. Of those who would flrst turn to an agency, the largest proportion would go in the event of unemployment.

In the financial emergency situation, there existed a difference between groups. "Relative" was the modal response (fifteen responses, $n=29$ ) and first source of ald for those forty-five and younger; "relative" and "commercial agency" (nine responses each, $n=30$ ) were the modal responses for those persons over forty-five. In both the marital and child disclpline problem situations, "I would not seek any help" was the modal response of those over forty-five (thirteen responses, $\mathrm{n}=28$ and ten responses, $\mathrm{n}=29$ ), while "friend" was the modal first source of a1d for those forty-flve and younger (ten responses, $n=30$ and ten responses, $n=29$ ). W1th respect to unemployment, both respondent groups cited "commercial agency" as the flrst and modal source of ald to which they would turn. Regarding percelved usefulness for a Chinese person to know about local social services, the majority of both groups felt such information to be "very 
useful" or "somewhat useful." The modal response of both those over forty-five and those forty-five and younger pertaining to supposed adequacy of services of an agency was "unsure." A Chinese person going to an agency was viewed as "very acceptable" or "somewhat acceptable" by the majority of both groups. The major1ty also agreed in feeling that there would not exist a language barrier if they were to go to a social service agency.

Household Income Level

The 1971 median household income of the respondents was $\$ 12,533$; because of the categorlcal nature of the data, and for the purpose of analysis, the respondents have been divided Into two groups: those having a 1971 household income of less than $\$ 12,000$, and those having $\$ 12,000$ or more. 
TABLE V

DESIRE FOR INFORMATION ABOUT

LOCAL SOCIAL SERVICES, BY

HOUSEHOLD INCOME LEVEL

\begin{tabular}{llc}
\hline & $\frac{\text { Desire Information }}{\text { Yes }}$ \\
\hline & & 4 \\
Less than $\$ 12,000$ & 27 & 17 \\
$\$ 12,000$ and Up & 20 & 4 \\
\hline
\end{tabular}

Regarding knowledge about soclal services, there was little difference between groups. The majority of both had never used the services of an agency and felt unfamiliar with the kinds of services offered. The majority of both income groups sald they would like the names and services of the Portland metropolitan area public and private agencies; however, the largest proportion of those who wanted this information were in the lower income groups.

Table VI shows where respondents would go as a first source of a1d in four problem situations. 
TABLE VI

LIKELIHOOD OF USING RESOURCES, BY HOUSFHOLD INCOME AND

TYPE OF PROBLEM

FINANCIAL EMERG ENCY

$\begin{array}{lccc} & \text { Agency } & \text { Other } & \text { Seek No Help } \\ \text { Less than } \$ 12,000 & 2 & 25 & 2 \\ \$ 12,000 \text { and Up } & 2 & 28 & 7\end{array}$

MARITAL PROBLEMS

$\begin{array}{lccc} & \text { Agency } & \text { Other } & \text { Seek No Help } \\ \text { Less than } \$ 12,000 & 3 & 15 & 12 \\ \$ 12,000 \text { and Up } & 4 & 17 & 12\end{array}$

CHILD DISCIPLINE PROBLEMS

$\begin{array}{lcccc} & \text { Agency } & \text { Other } & \text { Seek No Help } \\ \text { Less than } \$ 12,000 & 1 & 16 & 10 \\ \$ 12,000 \text { and Up } & 2 & 21 & 10\end{array}$

UNEMPLOYMENT

\begin{tabular}{lccc} 
& Agency & Other & Seek No Help \\
Less than $\$ 12,000$ & 5 & 20 & 2 \\
$\$ 12,000$ and Up & 5 & 23 & 6 \\
\hline
\end{tabular}


As to attltudes concerning social services, there was little difference between groups regarding first seeking ald from an agency in the listed situations; only a small number from each group would first go to an agency. Of those who would first go, the largest proportion would go in the event of unemployment.

In financial emergency, "relative" was the preferred first source of aid for the lower income group and the modal response for the higher income group; though "commercial agency" followed behind by one response for those in the higher income group. "I would not seek any help" was the modal response for both groups of respondents in marital and child disc1pline problems. However, "teacher" was listed as second most frequent response close behind "I would not seek any help" by the $\$ 12,000$ or more group in the child discipline problem situation. For the unemployment situation question, both groups listed "commercial agency" as the modal response.

Regarding the perceived usefulness for members of the Chinese community to know about local social services, the majority of both income groups felt this to be "very useful" or "somewhat useful." As to the supposed adequacy of services of an agency, little difference existed between groups as both listed "unsure" 
as the modal response. The majority of both income groups also felt that 1t was "very acceptable" or "somewhat acceptable" for a Chinese person to go to an agency for a1d. W1th respect to whether or not a language barrier would exist if the respondent went to an agency for ald, the majorlty felt there would not be such a barrier. Of those who felt a barrier would exist, the majority were in the below $\$ 12,000$ group.

\section{Education}

In this section, comparisons are made with respect to attltudes and knowledge concerning soclal services between respondents with less than a college education and those with some college or more.

There was little difference between the two groups with regard to knowledge about soclal services. The majority had not used the services of an agency and felt unfamiliar with services of fered. The majority of both respondent groups also expressed a desire to know the names and services of the public and private agencles in the metropolitan area.

Table VII shows use of soclal service agencles as a first source of a1d in four problem situations. 
TABLE VII

LIKELIHOOD OF USING RESOURCES, BY EDUCATION AND TYPE OF PROBLEM

\begin{tabular}{|c|c|c|c|}
\hline \multicolumn{4}{|c|}{ FINANCIAL EMERGENCY } \\
\hline & Agency & other & Seek No Help \\
\hline No College & 3 & 18 & 4 \\
\hline Some College or More & 1 & 35 & 5 \\
\hline \multicolumn{4}{|c|}{ MARITAL PROBLEMS } \\
\hline & Agency & Other & Seek No Help \\
\hline No College & 2 & 10 & 11 \\
\hline Some College or More & 4 & 23 & 14 \\
\hline \multicolumn{4}{|c|}{ CHILD DISCIPLINE PROBLEMS } \\
\hline & Agency & other & Seek No Help \\
\hline No College & 4 & 9 & 9 \\
\hline Some College or More & 0 & 30 & 11 \\
\hline \multicolumn{4}{|c|}{ UNEMPLOYMENT } \\
\hline & Agency & Other & Seek No Help \\
\hline No College & 4 & 13 & 4 \\
\hline Some College or More & 6 & 34 & 4 \\
\hline
\end{tabular}


Concerning attitudes about social services, there existed little difference between education levels as to how many respondents would first turn to an agency for ald; only a small number in elther group would go to an agency first. As in the other three comparisons, among those persons who would first turn to an agency, the largest proportion would go in the event of unemployment.

In the financial emergency situation, those with no college clearly chose "relative" as the first and modal source of a1d; "commerclal agency" (seventeen responses, $n=41$ ) was the modal response of the other group, with "relat1ve" (fourteen responses, $n=41$ ) being the second most frequent response. "I would not seek any help" was the modal response of both-groups In the marital problem situation. Regarding the child discipline problems, "I would not seek any help" (nine responses, $n=23$ ) was the modal response of those w1th less than a college education, and "teacher" (thirteen responses, $\mathrm{n}=41$ ) for those w1th some college or more. ("Other," twelve responses, and "I would not seek any help," eleven responses, followed close behind the modal response.) "Commerclal Agency" was the modal first cholce of ald for both education levels in the unemployment situation question. 
Table VIII shows respondents' feelings regarding acceptability for a Chinese person to go to a social service agency.

TABLE VIII

ACCEPTABILITY FOR A CHINESE TO GO TO AN AGENCY FOR AID, BY EDUCATION

Acceptable Unacceptable Unsure

No College

Some College or More
11

33
0

1
13

9

A difference existed between the two groups on the question of acceptability for a Chinese to go to an agency for ald, as shown in Table VIII. Those with some college or more thought this was "very acceptable" or "somewhat acceptable" while "unsure" was the modal and majority response for the no college group. The majority of both education level groups did not feel a language barrier would exist were they to go to an agency for some type of ald.

There existed little difference in degree of usefulness that the two groups saw in members of the Chinese community knowing about local soclal services; 
the majority of both saw this as being "very useful" or "somewhat useful." The majority of both groups also felt "unsure" as to their supposed adequacy of services.

Summary of Comparisons

There was little difference between China and American born respondents with respect to knowledge and attitudes concerning social services. However, more China born than American born respondents wanted information about local soclal services.

Regarding the respondents compared according to age, there existed slight difference between those over forty-flve and those forty-five and younger as far as knowledge and attitudes about social services, but more of the older group desired information about local agencies and services.

The two groups compared as to 1971 household income (less than $\$ 12,000$ and $\$ 12,000$ and up) showed little difference between groups with respect to social service attitudes and knowledge.

There existed slight difference between the two education levels regarding knowledge about social services. With respect to attitudes, there was also little difference, except in regard to acceptability 
for a Chinese person to go to an agency for a1d. The majority with some college or more felt this to be "very acceptable" or "somewhat acceptable," while "unsure" was the major1ty response for those with no college. 


\section{CHAPTER V}

\section{SUMMARY AND RECOMMENDATIONS}

This chapter is divided into three parts: summary of findings and implications for practice, discussion of the study, and recommendations.

Summary and Implications

As Indicated by the review of literature, little soclal work research has been done regarding the Chinese in America. This research found that members of the Portland Chinese community are a falrly homogeneous group as far as knowledge and attitudes concerning social services. It was also found that there existed little difference within groups of respondents when compared according to country of birth, age, education, and household income level.

The researchers' initial impression, confirmed by the research, was that the Chinese are unfamiliar w1th local soclal work agencies and services. The second Initial impression, "the traditional 1dea that seeking help outside the family is not acceptable is still held by members of the Chinese community," was not confirmed In that the majority of the respondents considered going to an agency to be acceptable. However, most 
would not first go to an agency in the four problem situations. The third initial impression, that acculturation would have changed Chinese thought that seeking help outside the family is unacceptable, recelved tentative confirmation. Most of the respondents had lived in the United States for more than fifteen years and felt help-seeking at an agency was acceptable for a Chinese person. This is in contrast to the traditional perspective of keeping it within the family.

Briefly summarlzing the research findings, the majority of the respondents felt unfamillar with social service agencles and the services they offer, and expressed a desire to know about local agencles. The majority also felt it was acceptable for a Chinese to go to an agency for ald, though most would not first turn to one in the four listed problem situations. The respondents felt that some type of assistance to the elderly is the most useful service an agency could offer the Chinese community.

Some of the implications for soclal work practice are discussed below:

Portland area soclal agencies are not reaching the area's Chinese population, as evidenced by the respondents' expressed unfamillarity with services and 
desire to know about local agencles. Local soclal services need to reach out and make themselves known to the city's Chinese community.

Members of the Portland Chinese community feel 1t is acceptable for a Chinese to go outside of his family to an agency for ald, thus they are no longer completely of the old school of thought. Th1s means that soclal workers and the profession need to know more about this minority group and how to better work with Chinese clients. Thus much more as well as more detalled and specific research needs to be done regarding the Chinese in America as relates to soclal work.

Portland Chinese community members listed assistance to the aged as the most useful service an agency could offer to their community (and a large majority of the respondents over age forty-five wanted to know about local agencles). Perhaps an entrée for soclal work into the Portland Chinese community could be accomplished through offering a service to this group.

Discussion

A discussion of the major Iimitations of this study follows:

The sample 1s one limitation which must be considered here. Because of the small sample size, 
generalization to larger Chinese populations can only be made with reservation. Also the sample is not a random one, so again generalization must be made with reservation and qualification; however, the respondents may represent those who are most responsive in the Portland Chinese communlty in terms of social services. A blas toward higher education and higher income levels may be present, and those most likely to need services may be underrepresented. Also the small sample forced combination of categories, so that differences were obscured. Further studies need to be conducted on a more extensive scale with larger representative samples.

The design of the questionnalre is another limitation to be considered. The questionnalre for this exploratory study was of a general nature and not sufficlently discriminating. In further studies, the questions need to be more specific and differentlating. Also in the questionnaire, a definition was not given for "social work agencles and services," thus different respondents might have had different interpretations of the terms. The researchers may have been misled by some of the respondents' answers to these questions. The questionnalre as a method of obtaining data may not have been the most effective method in that the 
low response rate may have been in part due to the fact that some of the people in the sample could nelther read nor write English or Chinese. The use of Interviewing as a method may have alleviated this difficulty. Also, when the questionnalre was translated from 1ts English version to the Chinese version, some of the Chinese words might have carried a slightly different meaning from their English counterparts. Thus there may have been an undetected discrepancy in meaning in the two versions. Some of the terms used in the English version are unfamlilar and not widely used in the Chinese language; some of the respondents may have misunderstood the terms and given an answer which the question was not meant to elic1t. A positive quality of the questionnaire is that respondent answers remain anonymous and confidential and thus respondents may have felt freer in answering than they might have with interviews.

This study, although it is of an exploratory nature and has Iimitations, has contributed toward a beginning better understanding of the Chinese community in relation to social services for the researchers and, hopefully, for soclal work as a profession and for other Interested and concerned persons. 
Recommendations

The following recommendations are made by the researchers for professional purposes, after analyzing the findings and implications of the study.

of great 1mportance is the necessity for further research on all aspects of the Chinese community. The study showed that much more study of the Chinese commun1ty must be done in order to get a deeper insight into their attitudes and expectations about social services. Some 1ssues and concerns will entall a high degree of difficulty. For instance, because the major1ty of Chinese have had little if any experlence with social agencles, a study of their attitudes is more difficult to make than of those cultures who have had much experience with social services. A study conducted from different perspectives would clarify factors which were not explored by th1s study. And st1ll another plcture could be shown if research is done to examine the attitudes and opinions of caseworkers who have had Chinese clients.

Th1s study also constituted another plea that professionals should take initiative action to go into the Chinese community and get an objective plcture. Some of the social problems in the Chinese community are now known; for example, problems of the aged, and 1 it is now 
necessary for professional social workers to become involved in further identifying problems and their solutions. In addition, because of the traditional value of self-rellance of the Chinese, the professional should seek, through his work with individuals, groups, and communities, to help the Chinese find within the Chinese community the resources for solving both the problems that affect them individually and those that affect them as a group.

One benefit of such study is to make avallable material about the Chinese minority group for purposes of social work education. For the harmony of the larger soclety, and the effectiveness of dealing with the Chinese clients, it is necessary for the institutions to offer more courses and content concerning the Chinese community. This would not only offer a chance to draw the professionals' attention to this "silent minority," but also would present an opportunity for them to get a better understanding of the Chinese people.

This research experience also suggests that it is more effective to have Chinese social workers in this field to deal with the Chinese clients and thelr problems. Because of the sameness of the intimate cultural background and physical appearance, it is easier for 
the Chinese social worker to gain access into the Chinese community. The relationship between worker and client could be established much more easily if both were Chinese. Thus the obstacles in the process of casework could be reduced to a minimum. Even the language problem, which might be a vital barrier in casework, could be overcome if the worker could speak the same dialect as the cllent does.

The main value of this study, we feel, w1ll be in whatever stimulus it provides to better serve those in need of soclal services. 


\section{LIST OF REFERENCES}

Bethune, Donald Blalne, et.al., "A Study of the Social

Activity Patterns and Needs of the Unattached Aged Male in the Strathcona Area of Vancouver, 19651966," unpubl1shed Master's thes1s, School of Soclal Work, University of British Columbia, 1966.

Chen, Pe1-Ngor, "The Chinese Community in Los Angeles," Soclal Casework, Volume 51, Number 10, December 1970.

Doby, John T., editor, An Introduction to Soc1al Research, New York: Appleton-Century-Crofts, 1967.

Fantl, B., "Cultural Factors in Family Diagnosis of a Chinese Family," The International Journal of Soclal Psychlatry, Summer 1959, The Avenue PubI1shing Company, Volume $V$, Number 1 :

Fong, S. L. M., "Assimilation of Chinese in America: Change in Orientation and Social Perception," American Journal of Soclology, 71 : 265-273, November 1965.

Gask111, Pauline, "Ecology of Portland Chinese," unpub11 shed term paper for Social Ecology Class 426 , Portland State University, 1968.

General Population Characterist1c, Bureau of Census, U.S. Department of Commerce, 1970.

Gittler, Joseph, Understanding Minority Groups, John Wiley and Sons, New York, N.Y., 1955.

Historical Statistics of the United States, U.S. Census Bureau, 1967.

Hsu, Franc1s L. K., Americans and Chinese--Two Ways of Life, Doubleday and Company, Incorporated, Garden C1ty, New York, 1970.

Kung, S. W., Chlnese in American Life, Seattle, Washington, UnIversity of Washington Press, 1962.

Kuramoto, F. H., "What Do Aslans Want? An Examination of Issues in Soc1al Work Education," Journal of Education for Soclal Work, 7 (3): 7-18, 1971. 
Lee, Jung 0. K., "Some Aspects of Mental Illness Among Recent Immigrant Chinese, " unpublished Master's thes1s, School of Soc1al Work, Un1versity of British Columbia, 1961.

Lee, Rose Hum, The Chinese in the United States of America, Hong Kong University Press, Oxford Un1versity Press, 1960.

L1, Y1h-Yuan, The Character of the Chinese, Inst1tute of Ethnology, Academia Sin1ca, Ta1pel, Talwan, 1972 .

Llu, Hu1-Chen Wang, The Traditional Chinese Clan Rules, $\mathrm{J}$. J. August in Incorporated, Locust Valley, New York.

Liu Yu-Chen, "Interaction Within Chinese-American Families of Portland, Oregon, Resulting from Cultural Differences," unpublished Ph. D. dissertation, Oregon State University, 1951.

Oppenhe1m, A. N., Questionna1re Des1gn and Att1tude Measurement, New York, Bas1c Books, Incorporated, 1966.

Parten, Mildred, Surveys, Polls, and Samples: Practical Procedures, New York, Harper and Brothers, 1950 .

Ph1llips, Bernard S., Soclal Research: Strategy and Tactics, The MacMilian Company, New York, 1966.

Ross, Edward A., The Changlng Chinese, the Conflict of Orlental and Western Cultures in China, Century Company, New York, 1911.

Schofleld, Michael, Soclal Research, London, Helnemann Educational Books, 1969.

Selltiz, Clalre, Marle Jahoda, Morton Deutsch, and Stuart W. Cook, Research Methods in Soclal Relations, Henry Holt and Company, New York, 1959.

"Success Story of One Minority Group in U.S.," U.S. News \& World Report, December 26, 1966.

Sung, Betty Lee, Mountain of Gold, New York, The Macmilian Company, 1967. 
Van Kooten, T. C., Living in a New Country, Guardian Publishing Company, Ham1lton, Ontar1o, Canada, 1959.

Wong, Charlotte 01 Quon, "Personal Problems as Defined in Chinatown--What do the Chinese in New York's Chinatown Consider to be Personal Problems and How do They Feel They Should be Handled?" unpub11shed Master's thes1s, New York School of Soc1al Work, Columb1a Un1versity, December 1948.

Yuan, D. Y., "Chinatown and Beyond: The Chinese Population in Metropolitan New York, "Phylon, 27: 321332, Winter 1966. 


\section{APPENDIX}




\section{MOST USEFUL KIND OF SOCIAL SERVICE FOR CHINESE COMMUNITY}

The following are some of the more representative and most typical responses to the last 1tem on the questionnaire: "I feel that the most useful kind of service that a social work agency could offer to the Chinese community is ..."

\section{ASSISTANCE TO THE AGED}

1. "Agencies to help older people."

2. "Medical and welfare services to aged in community for the taxes pald thru [sic] wages of the Employed Chinese. Very few know how to obtain these services and suffer from lack of care and nutrition."

3. "Organize a Chinese Senior Citizen Retirement

4. "Help the old Folks who are poor and need help when sick."

5. Service to the aged."

6. "A service specializing in alding the older Chinese people that do not speak English."

7. "Care of aged in Chinatown."

8. (Translated from Chinese) "Take care of the old people who are alone in this country and have a language problem . . . They do not know the kinds of soclal services they can make use of and the benefits and privileges they are entitled to from the government . . . Some of them have no relatives in this country and have financlal dif- 
ficulties. They are sent to public homes for old people. They have language problems. The question which this respondent raises 1s: "Why is there not even one Chinese home for old people?"

9. (Translated from Chinese) "Establish nursing home for old people."

LANGUAGE EDUCATION FOR NON-ENGLISH SPEAKING CHINESE

1. "To help the older Chinese people who has [sic] a language type problem. The newer and most second generation born are fully adequate to cope with the American style. Only the forelgn born who moved into the U.S.A. and those that are unfamiliar to the area should require assistance."

2. "Try to erase language barriers." (For example, the old and non-English speaking people may not use the services even though they are qualifled.) 3. "To work with those that have a language problem--
to understand and communicate."

4. "In providing aide [sic] in situations 1nvolving the language barrler between people."

5. "To help non-English speaking Chinese to learn English and adapt to the community."

\section{VOCATIONAL HELP}

1. "Equal opportunity for jobs."

2. "Employment counselling service or vocational $\vee$
guldance." 
HEALTH AND MEDICAL CARE

1. "For everyone to be able to get health and medical care."

2. "Health service."

\section{MISCELLANEOUS SERVICES}

1. "Any one that doesn't have the stigma of welfare."

2. "To seek employment and assist in obtaining c1t1zensh1p."

3. (Translated from Chinese) "Cultural exchange without the political and religlous background... a reading place where Chinese people can gather together and read magazines, newspapers, books and novels which are published in China, Taiwan and Hong Kong."

4. "Soclal work agency with personnel who could speak

NEED FOR MAKING AVAILABLE SERVICES KNOWN

1. "Make known what they offer and say who could recelve help so that needy people would seek help there.

2. "To inform us what is avallable after other means have been explored, when in difficulty . . . Perhaps the Chinese Community should set up a permanent committee to help the old and indigent by introducing them to various agencies that can help solve their problems. Provide interpreter when necessary and follow through unt1l their needs are provided."

3. "General info. [sic] dispersed centrally and made known to Chinese also at central location which explain [sic] avallable services." 
TRADITIONAL PERSPECTIVES

(The following are also responses to the last 1tem on the questionnaire.)

1. "I belleve in the old tradition Chinese custom of preparing for emergencles and not be depending on social agency assistancy. [sic]. I do not belleve anyone should look forward to government aid but should be intelligent enuf [sic] to plan his own future--be independent. Work harder in your youth and not look for fringe benefits."

2. "None." 


\section{QUESTIONNAIRE}

For each question, please check $(V)$ the response which most closely matches your own, or, where indicated, f1ll in the blank with your response.

(1) General information.

Relationship to the head of the household

Your occupation

Number of people in household (excluding boarders)

Sex

Age

Marital Status

(2) Educational level. (Please check completed level.)

Some grade school __ Some college

Grade school

College Graduation

H1gh school

(3) Total income level for household for last year (1971)

$\$ \quad 0--\$ 3,999$

$\$ 12,000--\$ 15,999$

$\$ 4,000--\$ 7,999$

$\$ 16,000$ and Up

$\$ 8,000--\$ 11,999$

(4) The language spoken in your household is: Chinese English Both Other 
(5) The country of your birth is:

China

(Include Mainland China,

Talwan, and Hong Kong)

U.S.A.

Other

(6) You have lived in the United States:

Under 5 years

Between 5 and 10 years

Between 10 and 15 years

Over 15 years

(7) Which generation Chinese in America are you?

1st generation __ More than 3rd generation

and generation ___ Unsure

(8) Are most of your friends

Chinese _ Non-Chinese

(9) Have you ever used the services of a social work agency?

Yes

No

(10) How familiar are you with the kinds of services offered by soclal service agencles?

Very familiar

Unfam1liar

Somewhat familiar 
(11) List the types of social services with which you are most familiar
A.
C.

B.

(12) Has it ever happened that you needed soclal service but did not know which agency offered the appropriate services?

Yes ㄴ No

(13) If you had a financial emergency, where would you first go for ald?

Commercial Agency Soclal Service Agency

Friend Other

Relative I would not seek any help

(14) If you had marital problems, where would you first go for ald?

Friend Minister Relative

Social Service Agency Other

I would not seek any help

(15). If you had child discipline problems, where would you first go for ald?

Friend

Relative

Teacher

Social Service Agency other

I would not seek any help 
(16) If you were unemployed, where would you flrst go to seek Job advice?

Commercial Agency Frlend

Relat1ve Soc1al Service Agency Other I would not seek any help

(17) How useful do you feel it is for members of the Chinese community to know about local soclal service agencles?

Very useful Somewhat useful

Not too useful Not useful

Undecided

(18) Suppose you went to a soc1al service agency to obtain some type of ald, how adequate do you feel the service would be?

Very adequate Somewhat adequate

Somewhat inadequate Inadequate

Unsure

(19) How acceptable do you feel 1t is for a Chinese person to go to a social service agency to obtain some type of service?

Very acceptable Somewhat acceptable

Somewhat unacceptable Unacceptable Unsure

(20) Do you feel there would be a language barrier if you went to a social service agency to obtain some type of ald?

Yes No 
(21) Would you like to know the names and the services of the public and private social service agencies in the Portland metropolitan area?

Yes

No

(22) I feel that the most useful kind of service that a soclal work agency could offer to the Chinese Community is

If you have any additional comments or would like to answer any of the questions more fully, please use the back of the questionnalre.

Thank you again for your cooperation. 